\title{
KEPEMIMPINAN MANAJERIAL KEPALA SEKOLAH DALAM MENINGKATKAN PRODUKTIVITAS KERJA GURU DI SMA NEGERI 1 RASAU JAYA
}

\author{
Maika Wida Safitri, M. Asrori, Sukmawati \\ SMAN 3 Sungai Raya \\ Jurusan Ilmu Pendidikan FKIP Untan Pontianak \\ Email: maikawidasafitri@student.untan.ac.id
}

\begin{abstract}
This study aims to reveal Principal Managerial in increasing Teacher Work Productivity at State Senior High School 1 Rasau Jaya which includes: planning, organizing, motivating, and rewarding. The study used a descriptive approach. The research subjects were the Principal, Vice Principal of Curriculum, Vice Principal of Student Affairs, Head of Libraries, and Teachers. All subjects are teachers who teach at State Senior High School 1 Rasau Jaya. Data collection methods used interviews, documentation, and observation. The data analysis model uses data reduction, data presentation, and conclusions. Test the validity of the data using trials and triangulation. The results of the study show the following: 1) Planning can be done through identifying what will be programmed, how it will be programmed, who will be involved, when it will be implemented, and how it will be implemented. The product of the planning is in the form of a School Activity Plan 2) This organization is carried out by division, principal and function equipped with an explanation of the duties of each teacher, 3) Motivating is carried out verbally and non-verbally continuously with Target and self-evaluation techniques Progress, Expectation of results, and Social comparisons and 4) Rewards are carried out with techniques that maintain a conducive working atmosphere.
\end{abstract}

\section{Keywords: Leadership, Managerial, Work Productivity}

\section{PENDAHULUAN}

Produktivitas individu adalah bagaimana seseorang melaksanakan pekerjaannya atau unjuk kerja (job performance). (Sedarmayanti, 2017, p.65). Sedangkan Pendi Susanto (2015, p.163) mengemukakan bahwa: "Produktivitas pada dasarnya adalah keadaan atau proses yang memungkinkan diperolehnya hasil yang lebih baik dan lebih banyak". Selanjutnya, ILO dalam Ricky (2019, p.1) menyebutkan bahwa "Produktivitas adalah rasio antara output dari pekerjaan dan input dari sumber daya yang dipakai dalam proses menciptakan kesejahteraan". Berdasarkan pendapat tersebut, produktivitas kerja guru adalah pencapaian unjuk kerja (output) yang maksimal dan lebih baik oleh guru yang mencakup efisiensi dan efektivitas untuk meminimalkan sumber daya yang digunakan (input).

Secara tradisional, tugas dan jabatan guru secara utuh memiliki espektasi peran ganda ialah sebagai pendidik (educator) dan sebagai pengajar (teacher) (Diding, 2018, p.148).
Tugas guru bukan hanya mengajar saja, tetapi juga mendidik, membimbing, mengarahkan, melatih, dan mengevaluasi peserta didik. Semuanya itu harus dilakukan semaksimal mungkin oleh guru demi dihasilkannya output siswa yang berkualitas dan mampu bersaing untuk berprestasi di dunia kerja. Pada hakikatnya, guru sangat berperan penting dalam pembentukan karakter dan moral siswanya.

Seorang guru, sudah selayaknya mampu dan mau menjalankan tugas dan kewajibannya secara maksimal. Guru harus memiliki produktivitas kerja yang tinggi untuk dapat mendukung terwujudnya produktivitas sekolah yang baik demi mencetak generasi penerus bangsa yang berkualitas.

Produktivitas kerja guru dipengaruhi oleh banyak factor baik dari dalam dan dari luar diri guru itu sendiri. Untuk bisa memaksimalkan produktivitas, seluruh pihak terkait harus memaksimalkan factor pendukung dan meminimalkan faktor penghambat yang ada. Sangat banyak pihak 
yang harus berperan aktif dalam peningkatan produktivitas guru. Salah satu pihak tersebut adalah kepala sekolah. Sedarmayanti (2017, p.78) menyebutkan bahwa faktor manajemen sangat berperan dalam meningkatkan produktivitas kerja baik secara langsung maupun tidak langsung.

Sebagai pelaksana tugas manajerial, seorang kepala sekolah tentu harus berperan aktif dalam upaya peningkatan produktivitas guru agar dapat menghasilkan produktivitas sekolah yang baik. Dalam upaya peningkatan produktivitas ini kepemimpinan yang kuat yang harus dimiliki oleh kepala sekolah. Dia harus mampu mendorong dan memastikan seluruh pihak yang dipimpinnya memiliki produktivitas yang maksimal.

Kepemimpinan kepala sekolah adalah suatu tindakan yang dilakukan oleh kepala sekolah dalam usaha mencapai tujuan dari sekolah yang dipimpinnya. Tindakan tindakan jitu inilah yang diharapkan mampu memaksimalkan produktivitas kerja guru maupun tenaga kependidikan yang ada di sekolah. Kepala sekolah sebagai pelaksana kepemimpinan pendidikan yang tidak hanya memimpin organisasi tetapi juga memimpin sebuah komunitas menjadi sangat sulit karena harus memimpin banyak individu dengan latar belakang yang berbeda dan kondisi emosional yang selalu berubah setiap saat. Oleh karena itu kepala sekolah harus memiliki kecerdasan dalam segala bidang sehingga mampu mengarahkan lembaga pendidikannya untuk bisa bersaing dan unggul.

Ketidak pastian dan perubahan di sekolah sudah pasti terjadi. "Leaders must be able to cope effectively with uncertainty and continuous change" (Sara, David \& Robert, 2011, p.3). Banyak masalah yang ada terkait dengan produktivitas kerja guru. Faktanya banyak guru yang tidak termotivasi untuk berprestasi, kurang bersemangat dalam membentuk karakter siswa, hanya terfokus pada pembelajaran bukan membimbing, mengarahkan, melatih siswanya. Tetapi permasalahan-permasalahan tersebut tidak ditemukan di SMA Negeri 1 Rasau Jaya. Hal itulah yang mendorong penyusun ingin meneliti lebih lanjut, menggali informasi secara mendalam tentang apa saja yang dilakukan oleh kepala sekolah untuk dapat menjadikan guru-guru yang di pimpinya menjadi guru yang produktif.
Kepala sekolah sebagai pemimpin pembelajaran memegang peranan yang sangat penting terhadap produktivitas kerja guru. Sejalan dengan pendapat Riggio (2014, p.14) yang menyatakan bahwa: "managerial interpersonal skills as competencies that help managers understand, communicate with, motivate and influence others, and resolve conflicts in goal-directed organizational settings". Oleh karena itu, aspek-aspek tentang kepemimpinan khususnya keterampilan interpersonal inilah yang ingin digali dan dipelajari. Banyak sekali aspek kepemimpinan seperti fisik, intelektual, emosionalitas, sosialisasi, kepribadian, dan kemampuan moral. Seluruh aspek yang harus dikuasai oleh seorang kepala sekolah untuk membentuk sekolah produktif dari sumber daya manusia yang produktif dan berkualitas.

SMA Negeri 1 Rasau Jaya terletak di Jalan Pendidikan Nomor 6, Desa Rasau Jaya I, Kecamatan Rasau Jaya, Kabupaten Kuburaya, Provinsi Kalimantan Barat. Sekolah ini dipimpin oleh Bapak Drs Sukarni, yang kepemimpinannya patut dijadikan tauladan. Pada saat observasi peneliti mendapati beliau sudah berada di sekolah jauh lebih awal sebelum guru-guru, tenaga kependidikan, dan siswa datang ke sekolah. Ketauladanan yang beliau berikan mendorong seluruh unsur yang ada di sekolah untuk bisa datang lebih awal. Ini adalah salah satu dari cara kepemimpinan yang peneliti temukan.

Pada penelitian ini peneliti berharap untuk dapat menemukan factor-faktor kepemimpinan lainnya. Bagaiman seorang pemimpin memanajerial lembaga yang dipimpinya dengan gayanya masing - masing. Pemimpin harus memotivasi, mendorong untuk berprestasi, berkomunikasi dengan baik, benar, dan dapat menentramkan hati, serta menciptakan lingkungan dan iklim kerja yang nyaman di sekolah.

Motivasi dapat diartikan sebagai kekuatan (energy) seseorang yang dapat menimbulkan tingkat persistensi dan entusiasmenya dalam melaksanakan suatu kegiatan, baik yang bersumber dari dalam diri individu itu sendiri atau motivasi intrinsik maupun dari luar individu atau motivasi ekstrinsik (Syamsul Arifin, 2019, p.146).

Kepemimpinan yang dapat memberikan motivasi dengan baik, membuat guru-guru merasa betah, bekerja dengan ikhlas, penuh 
tanggung jawab, termotivasi untuk maju dan berprestasi, dan semangat kerjanya akan bertambah dari waktu ke waktu. Hal itu dikarenakan guru merasa dihargai, dibutuhkan, dan diakui kelebihannya. Dengan demikian produktivitas kerja guru semakin meningkat sehingga produktivitas sekolah yang tinggi dapat dicapai dengan mudah.

\section{METODE PENELITIAN}

Penelitian ini menggunakan metode penelitian naturalistik atau kualitatif. Dengan pendekatan kualitatif ini, penelitian dilakukan terhadap kondisi obyek alamiah tanpa rekayasa. Penelitian dilakukan untuk memahami dan mengungkapkan kenyataan yang ada dan terjadi di tempat penelitian.

Menurut Husna Asmara (2013, p.39), penelitian kualitatif adalah penelitian untuk memecahkan masalah dan menemukan teoriteori berdasarkan verifikasi data yang dikumpulkan di lapangan. Imam Gunawan (2017, p.85) menyebutkan bahwa penelitian kualitatif adalah penelitian yang bertujuan untuk mendapatkan pemahaman yang mendalam tentang masalah-masalah manusia dan sosial.

Penelitian kualitatif adalah penelitian untuk memecahkan masalah dan menemukan teori-teori berdasarkan verifikasi data yang dikumpulkan di lapangan (Asmara, 2013, p.39). Penelitian kualitatif memiliki tiga ciri pokok yaitu natural setting, mengutamakan makna, dan menemukan.

Sedangkan Raco (2010, p.56) menyatakan bahwa metode kualitatif memiliki beberapa sifat khasnya, yaitu penekanan pada lingkungan yang alamiah (naturalisticsetting), induktif (inductive), fleksibel (flexible), pengalaman langsung (direct experience), kedalaman (indepth), proses, menangkap arti (Verstehen), keseluruhan (wholeness), partisipasi aktif dari partisipan dan penafsiran (interpretation).

Penelitian kualitatif adalah penelitian yang bertujuan untuk mendapatkan pemahaman yang mendalam tentang masalahmasalah manusia dan social bukan mendeskripsikan bagian permukaan dari suatu realitas sebagaimana dilakukan penelitian kuantitatif dengan positivismenya (Gunawan, 2017, p.85). Sedangkan Tracy (2013, p.3) menjelaskan bahwa: "Qualitative research is about immersing oneself in a scene and trying to make sense of it - whether at a company meeting, in a community festival, or during an interview".

Berdasarkan peryataan tersebut dapat diketahui bahwa dalam penelitian kualitatif peneliti harus membenamkan diri dan memahami secara penuh terhadap hal yang ditelitinya.

Adapun jenis penelitian yang digunakan dalam penelitian ini adalah penelitian deskriptif. Penelitian deskriptif adalah penelitian yang dilakukan untuk mengetahui nilai variabel mandiri, baik satu variabel atau lebih tanpa membuat perbandingan antara variabel yang satu dengan variabel yang lain (Sugiyono, 2017, p.11). Adapun Tracy (2013, h.3) menjelaskan bahwa:

By describing the background and context of action, researchers can decipher a twitch and tell it apart from a wink and from a parody of a wink - and they may interpret the meaning(s) of all these gestures and help predict whether we are likely to see the behavior again.

Artinya: Dengan mendeskripsikan, peneliti akan bisa memahami suatu peristiwa atau permasalahan yang ada di sekolah.

Selanjutnya Miles (1994, p.28) menegaskan bahwa: "The main task is to describe the ways people in particular settings come to understand, account for, take action, and otherwise manage their day-today situations. Artinya: Mendeskripsikan adalah yang utama dari penelitian kualitatif.

Kehadiran peneliti sangat penting dalam penelitian ini karena sudah menjadi karakteristik penelitian kualitatif bahwa peneliti merupakan instrument utama (human instrument). Dalam penelitian ini peneliti hadir langsung ke sekolah untuk mengamati dan mengumpulkan data yang dibutuhkan.

Penelitian dilaksanakan di SMA Negeri 1 Rasau jaya yang berlokasikan di Jalan Pendidikan No. 6 RT 02, RW 01, Rasau Jaya I , Kecamatan Rasau Jaya. Kabupaten Kubu Raya, Provinsi Kalimantan Barat. Sekolah ini dipilih karena memiliki pendidik dan tenaga kependidikan yang memadai. Selain itu, SMA Negeri 1 Rasau Jaya merupakan sekolah yang memiliki banyak pengalaman di bidang manejemen kinerja karena telah berdiri dari tahun 1994. Dengan usianya yang telah mencapai 26 tahun, diharapkan dapat memberikan banyak informasi kepada peneliti 
tentang kepemimpinan kepala sekolah.

Sumber data dalam penelitian ini terdiri dari sumber data primer dan sumber data sekunder. Data primer adalah data dalam bentuk verbal dari informan. Informan dalam penelitian ini adalah kepala sekolah, pendidik, tenaga kependidikan, dan siswa SMA Negeri 1 Rasau Jaya. Data sekunder adalah data yang diperoleh dari dokumen-dokumen grafis yang ada di tempat penelitian dan dokumendokumen yang ada di SMA Negeri 1 Rasau Jaya baik yang dimiliki oleh sekolah, kepala sekolah, pendidik, tenaga kependidikan, maupun siswa.

Asmara (2013, p.48) menjelaskan bahwa:

Prosedur atau tahap-tahap penelitian kualitatif ini adalah: (1) tahap orientasi, (2) tahap eksplorasi, dan tahap member check. Tahap orientasi bertujuan untuk memperoleh gambaran yang lengkap dan jelas mengenai masalah yang diteliti. Hal yang perlu dipahami pada tahap orientasi adalah: (1) pemahaman latar penelitian dan persiapan diri, (2) tata cara memasuki lapangan, dan (3) peran serta dan pengumpulan data.

Sedangkan pada tahap eksplorasi atau sering disebut sebagai tahap pekerjaan lapangan ini sudah dimulai penelitian. Adapun teknik pengumpulan data dalam penelitian ini dilakukan dengan observasi partisipan, wawancara mendalam, dan studi dokumentasi.

Teknik pengumpulan data dengan observasi digunakan bila, penelitian berkenaan dengan perilaku manusia, proses kerja, gejala-gejala alam dan bila responden yang diamati tidak terlalu besar (Sugiyono, 2017, p.166). Adapun Raco (2010, p.139) menjelaskan bahwa:

Peneliti melakukan observasi terhadap cara kepemimpinan yang dilakukan oleh kepala sekolah dan keadaan produktivitas guru yang ada di SMA Negeri 1 Rasau jaya. Observasi dilakukan kepada kepala SMA Negeri 1 Rasau Jaya, Bapak Drs. Sukarni, dewan guru sejumlah 43orang dengan 22 orang guru PNS dan 21 guru honor, enam tenaga kependidikan, dengan dua orang PNS dan empat orang lainnya honor.

Wawancara (interview) dilakukan untuk mendapatkan informasi, yang tidak dapat diperoleh melalui observasi atau kuesioner. (Raco, 2010, p.139). Wawancara pada penelitian ini dilakukan terhadap Kepala
Sekolah, pendidik, tenaga kependidikan, siswa, orang tua siswa, dan masyarakat. Peneliti menanyakan kepada responden tentang langkah langkah yang dilakukan oleh kepala sekolah dalam meningkatkan produktivitas kerja guru. Selain itu penelitiu juga menanyakan realitas produktivitas kerja guru yang ada di SMA Negeri 1 Rasau Jaya secara mendalam.

Dokumentasi merupakan suatu pengumpulan bukti dan keterangan selama proses pencarian data. Hasil dokumentasi bisa berupa foto, rekaman suara, ataupun berkas. Dokumen yang diteliti mencakup dokumen kelengkapan sekolah sekolah, dokumen Kepala Sekolah, dan dokumen perangkat kelengkapan pembelajaran guru.

Miles dan Huberman (2014, p.30) menjelaskan bahwa: "The words we collect and analyze are based on observations, interviews, documents, and artifacts. Such data are not usually immediately accessible for analysis but require some type of processing". Data yang telah kita peroleh di lapangan kita olah kembali dengan mereduksi, menyajikan, dan menyimpulkannya.

Mereduksi data adalah mengambil datadata yang yang sesuai dengan yang diharapkan dari banyak data yang telah dikumpulkan. Miles dan Huberman (2014, p.30) menjelaskan bahwa reduksi data dapat dilakukan dengan kondensasi data.

Data condensation refers to the process of selecting, focusing, simplifying, abstracting, and/or transforming the data that appear in the full corpus (body) of written-up field notes, interview transcripts, documents, and other empirical materials. By condensing, we're making data stronger. (We stay away from data reduction as a term because that implies we're weakening or losing something in the process).

Pada tahap ini dipilih data yang relevan dengan maksud penelitian, kemudian disederhanakan, dan di klasifikan berdasarkan tema dengan memadukan, dan merekomendasikan data tambahan yang selanjutnya dilakukan abstraksi data kasar menjadi uraian singkat.

Data yang disajikan adalah data yang telah diseleksi atau direduksi. Seperti yang dinyatakan oleh Miles (2014, p.31) bahwa:: "Generically, a display is an organized, compressed assembly of information that 
allows conclusion drawing and action".

Adapun data yang disajikan dalam penelitian ini adalah data yang berkenaan dengan: (1) Pembangunan dan penjagaan visi sekolah, (2) pembagian kepemimpinan, (3) kepeemimpin komunitas pembelajaran, (4) pemanfaatan data untuk membuat keputusankeputusan pengajaran, (5) pemonitoran kurikulum dan pengajaran

Miles dan Huberman (2014, p.37) menegaskan bahwa: "Conclusion drawing, in our view, is only half of a Gemini configuration. Conclusions are also verified as the analyst proceeds".

Kesimpulan merupakan hasil dari penelitian yang merupakan informasi yang diperoleh dari hasil penelitian. Dalam hal ini diperoleh informasi tentang kepemimpinan kepala sekolah yang berkenaan dengan perencanaan, monitoring, evaluasi, dan pengembangan kinerja dalam pencapaian produktivitas SMA Negeri 1 Rasau Jaya.

Lapan (2012, p.29) menjelaskan bahwa: "Credibility is the qualitative parallel to internal validity (the confidence that a researcher has that his or her intervention caused the change in the dependent variable)". Kredibilitas merupakan ukuran tentang kebenaran data yang diperoleh dengan instrumen. Apakah instrumen tersebut mengukur variabel yang sesungguhnya. Bila ternyata instrumen terebut tidak mengukur variabel yang sesungguhnya, maka data yang diperoleh tidaklah sesuai dengan kebenaran.

Untuk memenuhi standar kredibilitas, peneliti memperpanjang waktu di lapangan, jadi ditargetkan pada bulan April hingga Mei, peneliti memaksimalkan kehadiran di lapangan. Agar peneliti bisa lebih memahami secara mendalam objek penelitian yang ada. Selain itu peneliti juga melakukan pengamatan secara tekun dalam proses penelitian.

Memperpanjang waktu dilapangan, dan melakukan pengamatan secara tekun bertujuan agar dapat menggali informasi secara mendalam, sehingga tidak terjadi pemahaman yang salah terhadap pencarian data. Dengan melakukan penelitian dalam waktu yang lama dan melakukan pengamatan secara tekun, peneliti mendapatkan informasi tentang tujuan penelitian secara maksimal.

Raco (2010, p.111) menyebutkan: "Perolehan data dengan berbagai macam cara ini disebut triangulasi (triangulation)". Selanjutnya Denzin dalam Sarah J Tracy (2013, h.40) menyatakan: "triangulate - to use multiple types and sources of data, diverse methods of collection, various theoretical frames, and multiple researchers".

Sedangkan Michael Quin Patton (2015, h.1283) menjelaskan bahwa: "Triangulation in qualitative inquiry involves gathering and analyzing multiple perspectives, using diverse sources of data, and during analysis, using alternative frameworks".

Selanjutnya Denzin dalam (Patton, p.81) menyebutkan:

Four basic types of triangulation: (1) data triangulation - the use of a variety of data sources in a study, (2) investigator triangulation-the use of several different researchers or evaluators, (3) theory triangulation - the use of multiple perspectives to interpret a single set of data, and (4) methodological triangulation - the use of multiple methods to study a single problem or program.

Asrori (2019, p. 137), menyatakan bahwa teknik triangulasi merupakan modus pelacakan atau pengecekan kepada pihak ketiga atau sumber data ketiga guna meningkatkan peluang-peluang agar temuantemuan riset dan interpretasi terhadap temuantemuan riset itu menjadi lebih kredibel.

Triangulasi yang digunakan dalam penelitian ini adalah triangulasi teknik, triangulasi sumber, dan perpanjangan waktu pengamatan. Sugiyono (2020, p.125), menyatakan bahwa triangulasi teknik berarti peneliti menggunakan teknik pengumpulan data yang berbeda - beda dengan teknik yang sama.

Selanjutnya Sugiyono (2020, p.125) juga menjelaskan: "Triangulasi sumber berarti untuk mendapatkan data dari sumber yang berbeda-beda dengan teknik yang sama. Dalam proses triangulasi peneliti juga harus memperpanjang waktu penelitian. Raco (2010, p.78) menyebutkan bahwa: "peneliti harus meluangkan waktu yang cukup lama untuk benar-benar memahami kondisi tempat penelitian. Tujuan penelitian bukan hanya sekedar pembuktian, tetapi memahami dan menemukan". Penelitian Kualitatif dilakukan dengan tahap: (1) Deskripsi, (2) Reduksi, dan (3) Seleksi (Sugiono, 2013, p.234). Berdasarkan pernyataan Sugiono, peneliti 
juga melaksanakan ketiga tahap tersebut.

\section{HASIL PENELITIAN DAN PEMBAHASAN \\ Hasil}

Pengorganisasian yang ditemukan di SMA Negeri 1 Rasau Jaya dilakukan dengan menempatkan guru-guru sesuai dengan bidang keahliannya masing-masing. Penempatan guru tersebut selalu dipantau pelaksanaannya dan memungkinkan dilakukan roling apabila ditemukan ketidaksesuaian pelaksanaan proses pembelajaran

Pemotivasian yang ditemukan dilakukan kepala sekolah dengan cara: 1) memberikan contoh, 2) pemenuhan sarana prasarana penunjang kerja guru, 3) menjalin hubungan dan iklim kerja yang baik antar guru, dan pemantauan setiap saat oleh kepala sekolah.

Penghargaan yang diberikan oleh kepala sekolah terhadap kinerja guru dilakukan dengan pemberian jabatan dan tugas tambahan kepada guru tersebut sehingga secara otomatis guru tersebut memperoleh penghasilan lebih dibandingkan dengan guruguru yang lain.

\section{Pembahasan}

Temuan perencanaan dilakukan di awal tahun pelajaran dan dituangkan dalam Rencana jangka Pendek sekolah sesuai dengan pendapat Hope dan Player dalam Wibowo (2017, p.38) yaitu: "perencanaan strategis adalah suatu proses untuk menentukan tujuan jangka menengah dan panjang, dan bagaimana organisasi mencapainya".

Proses tersebut, dilakukan di SMA Negeri 1 Rasau Jaya melalui rapart yang diselenggarakan di setiap awal tahun ajaran. Rapart yang diselenggarakan di SMA Negeri 1 Rasau Jaya dalam proses perencanaan program dihadiri oleh seluruh guru yang ada. Dalam rapart ini seluruh guru berhak untuk menyampaikan aspirasinya dengan tujuan pencapaian tujuan sekolah dan menyempurnaan program kerja yang di usulkan oleh Kepala Sekolah bersama dengan wakil-wakilnya. Hal tersebut sesuai dengan pernyataan Mulyasa yang menyebutkan bahwa:

Kepala Sekolah hendaknya mampu menciptakan suasana rapat yang terbuka dan menyenangkan. Suasana rapat bersifat kekeluargaan tetapi tetap professional karena setiap tenaga kependidikan berbicara secara objektif, jujur, serta tidak memiliki syak wasangka yang bersifat negative dan merusak suasana rapat. (Mulyasa, 2019: 267)

Perencanaan sumber daya manusia dalam penyelenggaraan sekolah juga dilakukan secara matang dan dengan pertimbangan yang cukup. Merencanakan sumber daya manusia yang dilibatkan dalam meningkatkan produktivitas kerja guru dilakukan dengan mengidentifikasi ketersediaan guru PNS yang di SK kan oleh Pemerintah Provinsi Kalimantan Barat, dan kekurangannya dilakukan dengan pengangkatan tenaga honor.

Perencanaan sumber daya manusia ini telah dilakukan dengan cermat dan dengan analisis yang tepat. Dalam hal ini Kepala Sekolah telah memiliki keterampilan dalam memecahkan masalah berdasarkan analisis dan konsepsional. Hal ini sesuai dengan teori Dubin yang menyebutkan:

Keterampilan konseptual adalah kemampuan yang harus dimiliki oleh Kepala Sekolah untuk melihat sekolah sebagai suatu keseluruhan, merencanakan perubahan, merancang tujuan sekolah, membuat penilaian secara tepat tentang efektivitas kegiatan sekolah dan mengkoordinasikan program secara harmonis. (Dubin dalam Wahyudi, 2019, p.33)

Pernyataan lainnya tentang kemampuan Kepala Sekolah juga diberikan oleh ahli yang menyatakan: Kepala Sekolah harus berfikir secara analistik dan konsepional (must think analytically and conceptionally) dimana setiap Kepala Sekolah harus dapat memecahkan persoalan melalui suatu analisis, kemudian menyelesaikan persoalan dengan satu solusi yang feasible. (Wahjosumidjo, 2010, p. 98)

Merencanakan sarana prasarana yang akan digunakan dalam meningkatkan produktivitas kerja guru telah dilakukan. Dari hasil penelitian dapat diketahui bahwa sarana dan prasarana yang ada di SMA Negeri 1 Rasau Jaya telah direncanakan sedemikian strategis. Dari perencanaan tersebut, dihasilkan sarana prasarana yang cukup memadai untuk mendukung produktivitas kerja guru. Hal ini sesuai dengan pernyataan Pendi susanto (2016, p. 240) yaitu: "Fasilitas pembelajaran merupakan salah satu aspek 
Jurnal Kajian Pembelajaran dan Keilmuan Vol. 5 No.2, Oktober 2021-Maret 2022

terkait dengan upaya peningkatan produktivitas sekolah".

Anggaran juga direncanakan, ada dana yang dialokasikan untuk meningkatkan produktivitas kerja guru. Pengalokasian dana tersebut sesuai dengan juknis yang telah ditentuka dalam BOS maupun PBP. Penganggaran disesuaikan dengan kemampuan sekolah dengan memaksimalkan pemenuhan kebutuhan guru. Hal tersebut dilakukan mengingat banyaknya kebutuhan yang harus dipenuhi sekolah dari sumber dana yang ada. Hal tersebut sesuai dengan pernyataan Wahjosumidjo yaitu:

Disamping untuk keperluan gaji dan pengadaan material, masih banyak lagi dana yang harus dikeluarkan untuk berbagai keperluan seperti: (1) ekstensi atau perluasan tahun dan hari sekolah, (2) perbaikan preservice dan inservice program persiapan, (3) mengadakan jenjang pilihan karir para guru, (4) melaksanakan program pengajaran individual, (5) mempertinggi persyaratan tamatan sekolah menenngah atas, (6) menetapkan kompetensi minimal di dalam keterampilan dasar, dan (7) menyelenggarakan kursus-kursus tambahan program computer dan program-program spesialisasi lain. (Wahjosumidjo, 2010, h. 308)

Karena produktivitas kerja guru mencakup unjuk kerja guru dalam proses pembelajaran dengan indicator: kualitas, ketepatan, semangat kerja, motivasi, dan ketercapaian tujuan maka dalam rapat ini juga ditentukan bagaimana, kapan, dan standard pencapaian rencana kegiatan sekolah. Semua guru bebas mengemukakan pendapat terhadap draft yang telah disusun dan diajukan oleh Kepala Sekolah beserta wakil-wakilnya. Bebas mengemukakan pendapat juga merupakan demokratisasi yang menjadi salah satu usaha dalam upaya peningkatan produktivitas kerja guru sesuai dengan pernyataan ahli sebagai berikut:

Satu kiat yang ampuh dalam pemberdayaan sumber daya manusia dalam organisasi adalah penerapan gaya manajemen yang partisipatif melalui proses demokratisasi dalam kehidupan berorganisasi. (Siagian, 2009, p. 14)

Dengan demokratisasi ini guru-guru merasa memiliki andil dalam program yang dirumusukannya. Sehingga dia berusaha untuk melaksanakannya dengan penuh tanggung jawab.

Langkah - langkah yang nampak nyata dilakukan dalam upaya peningkatan produktivitas kerja guru di SMA Negeri 1 Rasau Jaya diantaranya: (1) supervisi, (2) finger, (3) CCTV di seluruh ruang kelas dan ruang kerja, (4) pemenuhan seluruh kebetuhan guru dalam mendukung pekerjaannya, (5) pendatangan nara sumber untuk memotivasi guru, (6) penciptaan lingkungan kerja yang aman, nyaman, rapi, dan menghibur, (7) penyediaan ruang website sebagai wadah pengembangan diri guru, (8) penempelan kalimat-kalimat motivasi dalam baliho yang ada di lingkungan sekolah, dan (9) pembudayaan iklim kerja sekolah yang harmonis.

Namun upaya - upaya yang dilakukan oleh Kepala Sekolah tersebut tidak tertuang dalam dokumen tertulis dalam suatu program kerja yang tersusun secara sistematis. Karena apabila hal tersebut dituangkan dalam program kerja yang tertulis, maka pelaksanaannya akan lebih sistematis dan tersruktur sehingga peningkatan produktivitas kerja guru tersebut akan memperoleh hasil yang maksimal.

Tujuan sekolah menjadi perhatian dan muara utama dari peningkatan produktivitas kerja guru itu sendiri. Karena seorang pemimpin memang harus berorientasi pada tujuan. Hal itu seperti pada teori berikut: "leadership includes attention to goals, this means that leadership has to do with directing a group of individuals toward accomplishing some task or end" (Peter G Northouse, 2007, h.3).

Perencanaan di SMA Negeri 1 Rasau Jaya telah dilakukan melalui pengidentifikasian apa yang diprogramkan, bagaimana cara pemrogramannya, siapa yang akan dilibatkan, kapan pelaksanaannya, dan bagaimana cara pencapaiannya. Produk dari perencanaan tersebut berupa Rencana Kegiatan Sekolah. Dengan demikian langkah yang ditempuh pihak sekolah dalam Perencanaan Kepemimpinan Manajerial Kepala Sekolah dalam Meningkatkan Produktivitas Kerja Guru di SMA Negeri 1 Rasau Jaya sudah sesuai dengan teori yang di kemukakan oleh Richard L. Daft yang mengemukakan bahwa perencanaan (planning) adalah mengidentifikasi berbagai 
tujuan untuk kinerja organisasi di masa mendatang serta pengunaan sumber daya yang diperlukan untuk mencapainya dengan 5W (what, why, who, when) dan 1h (how).

Teknik perencanaan yang dilakukan dan cara dalam pencapaiannya menunjukkan bahwa Kepala Sekolah telah memiliki ketrampilan konseptual yang bagus. Sesuai dengan pendapat Carver dalam Wahyudi (2019, p.33) yakni: "keterampilan Kepala Sekolah dalam menanggapi dan memahami serta cakap menggunakan metode-metode termasuk yang bukan pengajaran yaitu pengetahuan keuangan, pelaporan, penjadwalan, dan pemeliharaan". Bukti nyata dari bagusnya pengetahuan konseptual Kepala Sekolah juga dapat dilihat dari nilai Akreditasi pada komponen Standar pembiayaan yang sempurna yaitu 100 .

Pengorganisasian yang ditemukan oleh peneliti di SMA Negeri 1 Rasau Jaya telah dilakukan sesuai dengan keahlian masingmasing guru yang ada. Hal tersebut sesuai dengan pernyataan Wahjosumidjo (2010, p. 278) yang menyebutkan: "Tujuan pokok penempatan adalah, mencari kepastian secara maksimal, yaitu kesesuaian antara jabata atau tugas yang harus diisi dengan karakteristik pribadi para individu". Dengan penyesuaian tersebut diharapkan pelaksanaan kerja dapat dilakukan secara maksimal oleh individu yang ditugaskan, dan mampu menghasilkan unjuk kerja yang sesuai dengan kriteria yang ditetapkan.

Dalam proses pengorganisasian ini ternya dilakukan pemonitoran setiap saat. Contohnya saja pembagian tugas terhadap guru yang pelimpahannya telah dilakukan melalui pemberian SK dapat dicabut ketika pada prosesnya tidak sesuai dengan kriteria dan job description yang telah disepakati.

Evaluasi pembagian tugas terhadap guru yang dilakukan setiap akhir program. Namun, juga dilakukan perbaikan dan pemberian saran-saran yang mendukug. Pemberian saran dilakukan secara halus tanpa menyinggung guru dan tanpa menimbulkan image Kepala Sekolah yang sok pandai. Hal ini sesuai dengan teori komunikasi berikut:

Komunikasi merupakan penunjang terpenting bagi tim agar bisa menunjukkan kinerja terbaiknya. Komunikasi menjadi semacam pelumas untuk berlangsungnya interaksi produktif diantara sesame anggota tim. Komunikasi juga menjadi semacam bahan bakar yang membuat tim bisa berjalan dan fungsi serta peran yang ada di dalam tim bisa terlaksana dan berjalan dengan baik. (Syukri, 2017, p.209)

Dengan mengevaluasi pekerjaan guru setiap saat dengan pengkomunikasian yang baik akan mengurangi adanya ketidak sesuaian hasil kerja guru terhadap tujuan yang telah ditentukan. Dengan mampu menjalin komunikasi yang baik tersebut, nampak bahwa Kepala Sekolah telah memiliki keterampilan hubungan manusia dimana dijelaskan oleh Wahyudi (2019, p.73) bahwa Keterampilam hubungan manusia (human skills) adalah kemampuan seseorang dalam hal ini manajer dalam bekerja sama, memahami aspirasi dan memotivasi anggota organisasi guna memperoleh partisipasi yang optimal guna mencapai tujuan.

Selanjutnya disebutkan juga secara lebih rinci mengenai human skliss sebagai berikut: (1) Kemampuan untuk memahami perilaku manusia dan proses kerja sama, (2) kemampuan untuk memahami isi hati, sikap dan motif orang lain, mengapa mereka berkata dan berperilaku, (3) kemampuan untuk berkomunikasi secara jelas dan efektif, (4) kemampuan menciptakan kerja sama yang efektif, kooperatif, praktis, dan diplomatis, dan (5) mampu berperilaku yang dapat diterima. (Wahjosumidjo, 2010, h.101)

Kebijakan Kepala Sekolah dalam mengorganisasikan dan membebas tugaskan guru yang tidak sesuai tersebut semata-mata demin memaksimalkan pencapaian dari tujuan pembelajaran itu sendiri. Hal ini sesuai dengan pendapat Senge dalam Harry Tomlinson (2004, p.185) yang menyatakan bahwa: "The learning organizations as a model of how organizations should be structured if they are to achieve maximum learning".

Dengan demikian proses pengorganisasian yang dilakukan oleh Kepala Sekolah dengan menentukan tugas, mengelompokkan tugas, mendelegasikan dengan SK, dan memastikan sarana dan prasarana sebagai sumberdaya pendukungnya sudah sesuai dengan teori dari Ricard L.Daft dalam Aswandi (2018, p.61) yaitu:

Pengelolaan (organizing) mencakup: (1) menentukan tugas, siapa melakukan apa, (2) mengelompokkan tugas, (3) mendelegasikan 
otoritas, dan (4) mengalokasikan sumber daya di seluruh organisasi

Peneliti berpendapat bahwa akan lebih solid lagi apabila pengorganisasian yang dilakukan oleh Kepala Sekolah merencanakan adanya program pembentukan tim pembantu Waka agar kerja Waka menjadi lebih maksimal karena memang tugas yang harus dilakukan Waka sangatlah beragam. Apabila tim pembantu Waka terbentuk, pastilah produktivitas kerja Waka itu sendiri akan menjadi lebih baik lagi karena memperoleh tambahan sumber daya manusia untuk memperkaya kekuatan Waka tersebut. Seperti diketahui bahwa tim yang solid akan lebih cemerlang dalam produktivitas kerja.

Di SMA Negeri 1 Rasau Jaya pemotivasian telah dilakukan oleh Kepala Sekolah secara terus menerus. Temuan ini sesuai dengan pernyataan Robbins dalam Wibowo (2017, p.322) yang menyatakan bahwa: "Motivasi sebagai proses yang menyebabkan intensitas, arah, dan usaha terus menerus". Sedangkan Duncan W, Jack dalam Rahmat (2017, p. 43): "from a managerial perspective, motivation refers to any conscious attempt to imfluence behaviour toward the accomplishment of organizational goals". Upaya yang dilakukan oleh Kepala Sekolah tidak terbatas pada jenis dan bentuknya tapi berorientasi pada pencapaian tujuan sekolah.

(Schunk, Pintrich, \& Meece, dalam Richard, 2012) menyebutkan: "Motivation refers to the process whereby goal-directed activities are energized, directed, andsustained". Dari pernyataan ahli tersebut dapat difahami apabila motivasi mengacu pada proses dimana tujuan- kegiatan terarah diberi energi, diarahkan, dan berkelanjutan. Pemotivasian yang dilaksanakan secara berkelanjutan tersebut sesuai dengan yang dilakukan oleh Kepala Sekolah dimana beliau selalu memberikan motivasi kepada gurugurunya setiap saat. Bahkan ketika motivasi dalam diri gurunya mulai rendah, beliau selalu mengingatkan akan rasa syukur. Hal tersebut terbukti mampu meningkatkan produktivitas kerja guru. Bukti nyata dari bagusnya produktivitas kerja guru tertuang dalam nilai Akreditasi Sekolah yang mencantumkan nilai 99 pada standar proses, 96 pada standar pengelolaan, dan 100 pada standar penilaian pendidikan. Bukti nilai dapat dilihat dalam Lampiran 6. Dari nilai tersebut dapat disimpulkan bahwa guru telah unggul dalam proses pembelajaran di sekolah, unggul dalam pengelolaan sekolah, dan sempurna dalam melakukan penilaian pembelajaran. Produktivitas kerja yang sangat baik dan perlu untuk dipertahannkan.

Pemotivasian juga dilakukan dengan memenuhi seluruh sarana dan prasana yang dibutuhkan oleh guru-guru dalam menjalankan tugasnya. Kepala Sekolah dengan bantuan Waka sarpras selalu mengupayakan agar ruang kerja guru selalu bersih, nyaman, dan kondusif untuk bekerja. Hal tersebut sudah sangat tepat, sesuai dengan pernyataan Mulyasa (2019, p.120): "Seperti halnya iklim fisik, suasana kerja yang tenang dan menyenangkan juga akan membangkitkan kinerja para tenaga kependidikan".

Suasana kerja merupakan alat motivasi terbaik yang dapat digunakan dalan meningkatakan produktivitas guru. Hal tersebut sesuai dengan upaya Kepala Sekolah untuk tetap menjadikan suasana kerja yang ada di sekolah menjadi damai dan menyenangkan. Hal tersebut sesuai dengan teori:

Suasana tempat kerja yang dikelola dengan baik menciptakan kondisi-kondisi yang mendukung percarian karyawan akan makna, karenanya menyebabkan mereka merasa terkoneksi dengan tujuan-tujuannya. Untuk memotivasi pemimpin hanya perlu memanfaatkan kecenderungan alamiah orang untuk menemukan kepuasan intrinsic dalam pekerjaan mereka. (Jocelyn Davis, 2016, p. 202)

Selanjutnya Siagian (2009. p.23) juga menyatakan bahwa kondisi fisik yang menyenangkan sangat berperan dalam pemeliharaan kesehatan dan keselamatan kerja bahkan juga dalam mencegah terjadinya kejenuhan dan kebosanan. Selain itu juga dijelaskan hal-hal sebagai berikut:

Hal yang dimaksud dengan kondisi fisik yang menyenangkan ialah: (1) ventilasi yang baik, (2) penerangan yang cukup, (3) tata ruang yang rapi dan perabot yang tersusun baik, (4) lingkungan kerja yang bersih, dan (5) lingkungan kerja yang bebas dari polusi udara. (Siagian, 2009, p.23)

Proses pemotivasian yang dilakukan oleh Kepala Sekolah diawali dengan penyampaian tujuan sekolah dalam rapat penyusunan 
program di awal tahun ajaran. Dalam rapat itu juga disampaikan evaluasi terhadap program yang telah terlaksana sebelumnya dengan tujuan dan harapan untuk mendapatkan hasil yang lebih baik dari sebelumnya. Kepala Sekolah juga memberikan gambaran terhadap sekolah lain yang lebih maju sebagai motivasi untuk dapat mencapai kemajuan yang serupa. Yang dilakukan oleh Kepala Sekolah sesuai dengan yang dikemukakan oleh Dale $\mathrm{H}$ Schunk dan Ellen L. Usher (2012, p.18) yang mengemukakan bahwa proses pemotivasian terdiri dari: (1) Goals and self-evaluation of Progress, (2) Outcome expectations, (3) Values, (4) Social comparisons, and (5) Selfefficacy.

Dengan demikian proses pemotivasian menjadi hal yang penting dalam proses peningkatan produktivitas kerja. Pemotivasian yang dilakukan oleh Kepala Sekolah sudah sesuai dengan teori namun sebaiknya pemotivasian yang diberikan tersebut dapat diimbangi dengan peningkatan kemampuan guru itu sendiri secara terprogram.

Sistem penghargaan yang ditemukan oleh peneliti lebih mengarah kepada penghargaan moral. Kepala Sekolah lebih cenderung memberikan jabatan atau tugas tambahan kepada guru yang produktivitas kerjanya dianggap lebih baik dari yang lainnya. Pemberian jabatan atau tugas tambahan ini secara otomatis akan diikuti dengan pemberian insentif atau penghasilan lebih dan tidak akan menimbulkan kecemburuan sosial dan konflik antar guru. Hal tersebut sesuai dengan pernyataan sebagai berikut: "Kepala Sekolah harus berusaha menggunakan penghargaan secara tepat, efektif, dan efisien untuk menghindari dampak negative yang bisa ditimbulkannya." (Mulyasa, 2019, p.122).

Apapun bentuknya, penghargaan harus tetap diberikan oleh Kepala Sekolah karena sangat penting dalam memberikan dirongan dan semangat kepada guru. Hal tersebut sesuai dengan pernyataan berikut: "Sistem penghargaan sebagai suatu sarana untuk merangsang usaha ekstra dan identifikasi dengan organisasi itu". (William F Christopher, 2002, p.87).

Pemberian tugas tambahan yang lebih baik dan lebih tinggi posisinya, misalnya dengan memberikan tugas tambahan sebagai wakil Kepala Sekolah di bidang terentu merupakan suatu pengakuan yang dapat membuat guru tersebut meningkatkan produktivitas kerjanya. Teori tersebut merupakan teori motivasi Organizational Justice (Keadilan organisasi) yang didalamnya memuat Equity Ttheory. Sesuai dengan penjelasan sebagai berikut:

Karyawan menganggap partisipasi mereka di tempat kerja sebagai barter, dimana mereka memberikan kontribusi seperti keahlian dan kerja keras mereka, dan sebagai gantinya mereka mengharapkan hasil kerja baik berupa gaji ataupun pengakuan. (Adams dalam Asmara, 2017, p.67)

Teori lain menyebutkan: Pengakuan dari seorang pemimpin yang dihormati sangat dinilai tinggi oleh penerimanya (Chistopher, 2002, p.86). Dari sini dapat kita ketahui bahwa bukan hanya materi yang diperlukan, tetapi pengakuan juga sangat diperlukan untuk menjadikan motivasi dalam diri seseorang. Pemberian posisi lebih itulah yang merupakan salah satu pengakuan yang di lakukan di SMA Negeri 1 Rasau Jaya.

Menurut Jocelyn Davis (2016, p.203) pengakuan adalah seberapa besar orang merasakan mereka diakui dan dihargai atas kinerja yang baik. Dengan adanya pengakuan ini, guru akan merasa puas karena ternyata kerja keras yang dilakukannya mendapatkan perhargaan di mata orang lain. Dan tentu saja produktivitas kerja mereka akan lebih meningkat.

Dengan demikian, proses penghargaan yang dilakukan oleh Kepala Sekolah sudah sesuai dengan teori yang ada karena selalu memperhatikan situasi dan kondisi dari lingkungan kerja itu sendiri. Lingkungan kerja yang kondusif dan inspiratif menjadi perhatian utama Kepala Sekolah dalam proses penghargaan.

Berdasarkan hasil temuan diketahui bahwa guru-guru yang di SMA Negeri 1 Rasau Jaya sudah produktif dengan indikator:

(1) kualitas, (2) ketepatan, (3) kepuasan, (4) kemampuan adaptasi, (5) semangat kerja, (6) motivasi, dan (7) ketercapaian tujuan. Untuk mewujudkan produktivitas kerja guru tersebut, Kepala Sekolah telah berupaya secara maksimal untuk meningkatkan proses perencanaan, pengorganisasian, pemotivasian, dan penghargaan. Usaha yang dilakukan Kepala Sekolah tersebut sesuai dengan teori yang menyatakan: 
Faktor-faktor penentu keberhasilan upaya peningkatan produktivitas yaitu: (1) pebaikan terus menerus, (2) peningkatan mutu hasil pekerjaan, (3) pemberdayaan sumber daya manusia, (4) fisafat organisasi. (Siagian, 2009, h. 10)

Perbaikan terus menerus dilakukan oleh Kepala Sekolah dengan mengevaluasi program sebelumnya untuk dijadikan pertimbangan dalam proses perumusan program beriktnya. Selain itu Kepala Sekolah juga terus melakukan perubahan pada bidang IPTEK dengan merubah media pembelajaran online muali dari penggunaan media group whatsap, google classroom, zoom dan meet hingga menggunakan media edmodo yang dirasa lebih efektif dan sistematis.

Sumber Daya Manusia merupakan unsur yang paling penting dalam pencapaian tujuan sekolah. Pemberdayaan sumber daya manusia telah dilakukan dengan baik di SMA Negeri 1 Rasau Jaya, yang diawali dengan pembagian tugas sesuai dengan bidang keahlian masingmasing.

Mengingat pentingnya produktivitas kerja guru dalam proses pencapaian tujuan sekolah, memang sudah menjadi keharusan bagi Kepala Sekolah untuk memperhatikannya. Karena tujuan dari SMA Negeri 1 Rasau Jaya telah tercapai dengan baik maka pastilah produktivitas kerja guruguru di SMA Negeri 1 Rasau Jaya tergolong baik juga. Ketercapaian tujuan Sekolah dapat dilihat dari rata-rata Nilai Akhir siswa yang tergolong bagus yakni 84 untuk program IPA dan 82,09 untuk program IPS bukti nilai dapat dilihat pada Lampiran 28. Bukti nyata dari ketercapaian tujuan sekolah juga dapat dilihat dari banyaknya siswa yang diterima masuk di Perguruan Tinggi Negeri melalui program beasiswa. Dari data dapat dilihat bahwa 33\% siswanya telah melanjutkan di Perguruan Tinggi. Bukti dokumen dapat dilihat pada Dokumen1. Hal ini sesuai dengan Tujuan Jangka Pendek Sekolah yaitu nomor 1, 2, dan 3. Adapun Tujuan Jangka Pendek Sekolah adalah sebagai beriku:

(1) Siswa kelas XII tamat dan lulus $100 \%$, (2) Rata-rata nilai UNBK minimal 60.00 , (3) $50 \%$ lulusannya dapat melanjutkan ke Perguruan Tinggi Negeri, (4) terlaksananya proses pembelajaran secara interaktif, efektif, dan efisien, (5) siswa memiliki disiplin tinggi dalam belajar dan beribadah, meningkatnya profesionalisme guru dalam menjalankan tugas, (7) terpilihnya Siswa/siswi paskibraka untuk tingkat Kabupaten dan Provinsi, (8) menjadi juara olimpiade Sains, lomba mata pelajaran, olahraga dan kesenian minimal 3 juara tingkat Kabupaten, dan 2 juara untuk tingkat provinsi, (9) Memiliki WC siswa yang representative, (10) memiliki pagar yang representative, (11) memiliki taman sekolah yang asri dan indah, dan (12) memiliki Mushola yang representative

Menurut peneliti, sekolah harus lebih meningkatkan lagi jumlah siswa yang mau melanjutkan dan dapat diterima di Perguruan Tinggi Negeri. Selain itu, sekolah juga harus lebih memotivasi guru pembina Paskibra untuk dapat meningkatkan produktivitas kerjanya agar siswa/siswi dapat terpilih sebagai paskibra tingkat Kabupaten atau Provinsi sesuai dengan tujuan sekolah Nomor 7. Karena hanya dua tujuan sekolah yang belum tercapai secara maksimal dapat diketahui bahwa produktivitas kerja guru di SMA Negeri 1 Jaya sudah sangat bagus namun perlu ditingkatkan agar menjadi sempurna.

Buktin nyata dari tingginya produktivitas kerja guru di SMA Negeri 1 Rasau Jaya juga dapat dilihat dari nilai Akreditasi yang dicapai sekolah tersebut. Sekolah telah mampu mencapai predikat unggul dengan Nilai 96. Bahkan pada tiga komponen yakni Standar Isi, Standar Pembiayaan, dan Standar Penilaian Pendidikan mencapai nilai sempurna yaitu 100 .

\section{SIMPULAN DAN SARAN Simpulan}

Perencanaan di SMA Negeri 1 Rasau jaya dalam meningkatkan produktivitas kerja guru tertuang dalam program kerja sekolah. Salah satu program sekolah yaitu kurikulum kondisi khusus. Perencanaan yang dilakukan meliputi perencanaan kurikulum, perencanaan sumber daya manusia, dan perencanaan sarana prasarana. Dalam perencanaan, kepala sekolah beserta wakil-wakilnya melakukan penyusunan yang selanjutnya diadakan rapat bersama seluruh unsur sekolah.

Perencanaan dalam meningkatkan produktivitas kerja guru dilakukan melalui beberapa tahap, diantaranya: (1) Perumusan program kerja oleh Kepala sekolah dan 
wakilnya, (2) Mengkomunikasikan program kerja dalam rapat terbuka, (3) merevisi program kerja, (4) menentukan program kerja.

Pengorganisasian sekolah dalam upaya peningkatan produktivitas kerja guru di SMA Negeri 1 Rasau Jaya di lakukan dengan mengidentifikasi kemampuan masing-masing personal untuk bisa menempatkannya dengan tepat sesuai dengan keahliannya. Apabila dalam proses pelaksanaannya ditemukan berbagai masalah atau kendala yang mengurangi produktivitas kerja guru, maka akan dilakukan revisi, pergantian, roling untuk penyegaran, maupun pemberhentian

Dalam meningkatkan produktivitas kerja guru di SMA Negeri 1 Rasau Jaya pemotivasian dilakukan oleh kepala sekolah secara terus menerus. Ketika produktivitas kerja guru menurun, kepala sekolah melakukan motivasi kembali.

Motivasi diberikan baik secara verbal maupun non verbal. Insentif juga telah diberikan atas tugas tambahan yang telah diberikan kepada guru. Insentif ini juga merupakan salah satu bentuk motivasi yang diberikan. Bentuk motivasi lain adalah pemenuhan sarana dan prasarana guru dalam menjalankan tugasnya.

Dalam meningkatkan produktivitas kerja guru di SMA Negeri 1 Rasau Jaya pemotivasian dilakukan oleh kepala sekolah dengan cara: (1) Pemberian insentif atas tugas tambahan yang telah diberikan kepada guru, (2) pemenuhan sarana dan prasarana guru dalam menjalankan tugasnya, dan (3) pemberian sertifikat kepada guru yang menulis artiket dalam website sekolah.

Berdasarkan uraian di atas dapat kita ketahui bahwa kepala sekolah akan melakukan penyesuaian dan perbaikan selama proses pelaksanaan program demi tercapainya program secara maksimal. Dari proses tersebut dapat kita simpulkan jika kepemimpinan manajerial kepala sekolah di SMA Negeri 1 Rasau Jaya lebih cenderung menggunakan pendekatan situasional.

\section{Saran}

Saran yang bisa diberikan peneliti antara lain: 1) SMA Negeri 1 Rasau Jaya perlu menyusun struktur organisasi dari pembagian tugas yang telah dilaksanakan dan meletakkannya berjajar dengan visi, misi, dan tujuan sekolah agar semua orang dapat melihatnya dengan mudah, 4) Peningkatan produktivitas kerja guru sebaiknya diprogramkan dalam program sekolah secara lebih nyata untuk dapat dilaksanakan dengan pedoman yang jelas dan tertulis, 7) Pelatihan terhadap penggunaan dan pembuatan media pembelajaran sebaiknya diprogramkan dan dilaksanakan secara terus menerus agar guru lebih menguasai IT, 8) Pelatihan terhadap penyusunan artikel juga sebaiknya diprogramkan agar guru lebih mahir dan produktif dalam menulis sebagai bentuk dari pengembangan diri, 9) Ketidak hadiran guru yang terdeteksi dari finger sebaiknya dijadikan sebagai program pengembangan guru dengan cara mengikutkan guru dalam sebuah pelatihan sebagai bentuk hukuman yang membangun, 11) Website artikel sekolah sebaiknya juga memberikan wadah menulis bagi siswa selain majalah dinding, 12) Evaluasi produktivitas kerja guru sebaiknya dilakukan setiap bulan agar dapat dipastikan bahwa setiap guru telah memberikan dedikasi yang maksimal terhadap pencapaian program sekolah, 15) Bagi peneliti berikutnya untuk dapat menjadi bahan pertimbangan dalam melakukan penelitian yang sejenis nantinya.

\section{DAFTAR RUJUKAN}

Adair, J. (2010). Develop Your Leadership Skill. United Kingdom: Kogan Page.

Amin, M. M. (2016). Manajemen Mutu. Yogyakarta: Media Akademi.

Arifin, S. (2019). Leadership. Jakarta: Mitra Wacana Media.

Armstrong, B. (2005). Managing Performance. London: CIPD House.

Asrori, M. dan Mohammad A. (2019). Metodologi \& Aplikasi Riset Pendidikan. Jakarta: Bumi Aksara.

Aswandi. (2018). Manajemen Perubahan. Depok: Rajawali Pers.

Bugin, Burhan. 2017. Metode Penelitian Kualitatif. Depok: Rajawali Pers.

Chaniago, A. (2017). Pemimpin dan Kepemimpinan. Jakarta: Lentera Ilmu Cendikia. 
Christhopher, W. F dan Carl G Thor, diterjemahkan oleh Marcus $P$ Widodo. (2002). Mutu dan Produktivitas Berkelas Dunia. Jakarta: Prenhallindo Publisher.

Haryono, S. (2018). Kepemimpinan kepala sekolah SDM Teori \& Aplikasi. Jakarta: Luxima Metro Media.

Heaton, T. L. (2016). Handbook of Instructional Leadership. Ohio: Cedarville University.

Hery. (2019). Manajemen Kinerja. Jakarta: Grasindo.

Morril, R. AL. (2010). Strategic Leadership. USA: American Council On Education.

Mulyasa. (2019). Menjadi Kepala Sekolah Profesional. Bandung: Remaja Rosdakarya.

Nurdin, D. \& Bambang I. (2018). Administrasi dan Manajemen Sumber Daya Pendidikan. Bandung: Refika Aditama.

Priyono. (2007). Pengantar Manajemen. Sidoarjo: Zifatama Publishing.

Rahmat, A. dan Saiful K. (2017). Kepemimpinan Pendidikan dan Budaya Mutu. Yogyakarta: Zahir Publishing.
Riggio, R. E and Sherylle T. (2014). Leader Interpersonal and Influence Skill. New York \& London : Routledge.

Ryan, R.M. (2012). The Oxford Handbook of Human Motivation. USA: Oxford University Press.

Sanusi, A. (2013). Kepemimpinan Pendidikan. Bandung: Nuansa Cendikia.

Siagian, S. P. (2009). Kiat Meningkatkan produktivitas Kerja. Jakarta: Rineka Cipta.

Sugiyono. (2018). Cara Mudah Menyusun Skripsi, Tesis, dan Disertasi. Bandung: Alfabeta.

Wahyudi. (2015). Kepemimpinan Kepala Sekolah Dalam Organisai Pembelajar (Learning Organization). Bandung: Alfabeta 